\title{
SOME ASPECTS OF 1985 DEREGULATION OF PETROLEUM
}

\author{
ALAN S. HOLLINGWORTH AND JUDITH A. SNIDER*
}

\begin{abstract}
This paper discusses the impacts of the Western Accord on the movement of petroleum from wellhead to market. Specific matters dealt with include: pricing; various intraAlberta concerns such as prorationing, the role of the Alberta Petroleum Marketing Commission and the position of operators, and extra-Alberta concerns such as the export of petroleum, pipeline movement; and the role of governments.
\end{abstract}

\section{INTRODUCTION}

From September 1973 to May 31, 1985, Canada had a system of government-administered oil prices. On March 28, 1985 the Governments of Canada, Alberta, Saskatchewan and British Columbia entered into "The Western Accord, an Agreement Between the Governments of Canada, Alberta, Saskatchewan and British Columbia on Oil and Gas Pricing and Taxation" (hereinafter referred to as the "Western Accord"). To achieve the stated objective of:

... [modifying] the existing taxation and pricing regime in order to stimulate investment and job creation in the energy sector in Canads and to increase the degree of energy security for all Canadians,

provisions dealing with the "Deregulation of Crude Oil Prices" were included in the Western Accord.

These oil deregulation provisions have had a great impact on many aspects of production, marketing and transportation. The relevant provisions of the Western Accord are set out as principles in Clauses 1 to 10 and state:

IT IS AGREED that market pricing of oil is desirable and will be implemented as follows:

1. For the purposes of this understanding, 'oil' means crude oil, pentanes plus, synthetic oil and crude bitumen, unless otherwise stated.

2. Oil may be purchased from Canadian or foreign sources without restrictions on volume, and at prices freely negotiated between buyers and sellers, subject to Clauses 5 to 9.

3. The Government of Canada agrees, subject to Clauses 8 and 9, to remove the export charges on oil and petroleum products, the Oil Import Compensation Program and the Petroleum Compensation Charge.

4. Movement of crude oil and petroleum products between provinces, and for import and export purposes, shall be in accordance with federal and provincial legislation established for safety and/or environmental reasons.

5. Concerning the role of the National Energy Board (NEB):

i. Consistent with the move to market pricing, volume and price restrictions on short-term crude oil and petroleum product exports will no longer be required.

ii. The NEB will issue non-restrictive licences for short-term exports, on an afterthe-fact basis, to permit monitoring of volumes and prices. The NEB will report monthly to the Minister of Energy, Mines and Resources on these oil export matters. Distortions in the competitive market or particular problems associated with a free market which are identified through such monitoring will be addressed by the Minister of Energy, Mines and Resources as they arise, following consultation with provincial governments.

iii. The NEB will, in appropriate instances, ensure that export contracts for periods exceeding one month contain force majeure clauses. 
iv. Longer-term exports, of more than one year for light crude and petroleum products and two years for heavy crude (as defined by the NEB) will continue to require prior approval of the NEB and the Governor-in-Council.

v. The NEB's practice of allocating light crude oil among eastern Canadian refineries will be discontinued.

6. The producing provinces shall retain their power to control production of crude oil to ensure good conservation practice or, in the event of market constraints, to ensure equitable sharing of production.

7. Consistent with the spirit of deregulation, the Alberta Petroleum Marketing Commission will cease to act as the exclusive agent for the marketing of the Crown lessees' share of crude oil and pentanes and will, in its role as buyer and seller of oil in Alberta, be in competition with buyers and sellers of oil in the private sector.

8. In the event that supplies of crude oil and petroleum products to Canadian consumers are significantly jeopardized, the federal government, after consultation with producing provinces, may restrict exports to the extent it considers necessary to ensure adequate supplies to Canadians.

9. In the event of international oil market disturbances that result in sharp changes to crude oil prices, with potentially negative impacts on Canada, the Government of Canada, following consultations with provincial governments, will take appropriate measures to protect Canadian interests.

10. These principles, effecting oil deregulation for Canada, will come into effect on June 1, 1985.

The principles set out were welcomed whole-heartedly by the petroleum industry and it was with great enthusiasm and optimism that the June 1, 1985 date of deregulation was anticipated. However, very quickly the problems associated with implementing these principles began to surface and have continued to concern all participants in the oil industry.

The purpose of this paper is to address some of the provisions of the Western Accord relating to oil deregulation and how they have been and are being dealt with and implemented, mainly in the Alberta context, by the "players" in the oil deregulation game. In our definition of "players" we have included:

1. National Energy Board ("NEB")

2. Alberta Petroleum Marketing Commission ("APMC")

3. Energy Resources Conservation Board of Alberta ("ERCB")

4. pipeline companies

5. producers

6. federal and provincial governments.

We deal first with the most apparent result of deregulation; that being pricing. Next, we discuss some intra-Alberta effects and concerns, such as oil prorationing by the ERCB, the changed role of the APMC and changing effects on producers of oil. From Alberta concerns, we move to a review of federally-related matters, such as regulation of interprovincial pipelines and control of exports in the deregulation era. Lastly, we briefly observe the continuing roles of the provincial and federal governments.

For the purposes of this paper we have used, as our definition of "oil", that set forth in section 2 of the Energy Administration Act,' specifically:

'oil' means any hydrocarbon or mixture of hydrocarbons other than gas and includes an oil product.

Hydrocarbons are defined as excluding coal. 
[VOL. XXV, NO. 1

In no way is this paper exhaustive. New problems seem to appear every day and we caution the reader that updating this paper will be essential. However, we hope it will provide an overview of how oil deregulation is working to date.

\section{PRICING}

\section{A. PRE-DEREGULATION PRICING}

From September 4, 1973 when the price of Alberta oil was frozen in response to rapidly escalating world oil prices, Canada lived with ("endured", as some would say) regulated oil prices. Effective April 1, 1974, the federal government enacted the Petroleum Administration $\mathrm{Act}^{3}$ (now cited as the Energy Administration Act and referred to herein as the "EAA"), pursuant to which the following were authorized and administered:

1. the domestic price for oils

2. the subsidy for imported oil ${ }^{6}$

3. the export tax ${ }^{7}$

Simplistically stated, the scheme of the EAA, vis-à-vis pricing, was to achieve a uniform price for crude oil to all buyers in Canada. The frozen price was replaced over time with prices agreed to by the federal and Alberta governments in a series of Alberta-Federal oil pricing agreements. ${ }^{8}$ However, as appears to be the case with any regulated system, more complex regulation was needed to deal with particular concerns and inequities which became apparent. To attract investors, categories of 'new oil', which carried international prices, were created, beginning in 1978 with Syncrude synthetic oil production and extending later to the Suncor plant's output. New oil discoveries were gradually added to the exceptions. As a result, the pricing system had reached a point in 1985 where more than $50 \%$ of Canadian produced oil received the international price. ${ }^{8}$

\section{B. IMPLEMENTATION OF DEREGULATION}

Clauses 1 to 10 of the Western Accord sought to dismantle this pricing regime which, it has been alleged, "imposed serious restrictions on petroleum markets" and "inhibited the petroleum industry in meeting its full potential for creating jobs and stimulating economic renewal"..${ }^{10}$ The measures to result from the Western Accord are summarized in Appendix "A".

2. For a discussion on the pricing of oil up to 1976, the reader is referred to P. Tyerman, "Pricing of Alberta's Oil" (1976) 14 Alta. L. Rev. 427 and H. Ward, "Marketing and Pricing Legislation" (1975) 13 Alla. L. Rev. 73.

3. Supra n. 1 .

4. The Petroleum Administration Act was renamed the Energy Administration Act by S.C. 1980-81-82-83, c. 114, s-5. 2(1).

5. Energy Administration Act, S.C. 1974-75-76, c. 47, Part II, as am.

6. Id. at Part IV.

7. Id. at Part I.

8. Canada Department of Energy, Mines and Resources "Backgrounder - Crude Oil Price Deregulation" Communique 85/37, 28 March 1985.

9. Id. at 1 .

10. Id. 


\section{EFFECTS OF DEREGULATION ON OIL PRICING}

The immediate effect of the implementation of Clauses 1 to 10 was, as planned, to allow parties freely to negotiate oil prices with the consequent effect of permitting increased access to markets. The domestic market for crude oil is, to a great extent, considered to be mature; that is, there does not appear to be much room to create new markets within economical reach in Canada. However, the export market, and more specifically, the U.S. Midwest, has been the immediate target of the most aggressive marketing.

The following statistics" exhibit some of the post-deregulation trends:

1. Canadian export of light crude in the first nine months of 1985 almost equalled those for heavy crude. This was a reversal of the prederegulation trend;

2. Exports of light crude in the first nine months of 1985 more than doubled over the same 1984 period;

3. September 1985 exports of light crude increased by $69 \%$ to 2.6 million $\mathrm{m}^{3}$ (16.355 million barrels) while imports rose $72 \%$ to 1.7 million $\mathrm{m}^{3}$ (10.69 million barrels).

\section{Domestic Pricing ${ }^{12}$}

The largest domestic market for Canadian crude oil is located in Sarnia, where the major refiners are located. In this market, refiners are looking for a purchase price which will make them competitive with Chicago refiners. If Western Canadian sources cannot or will not provide a competitive price, the refiners can now arrange to buy offshore or from U.S. sources. The negotiated sale price will be affected by many factors, including the price Canadian producers receive for their oil in the Chicago market. In a period of over-supply, such as the presently prevailing one, the negotiations will no doubt favour the oil purchaser. To determine the netback price to the producer, the tariff for moving the production from the producer's battery to Sarnia, any sales commissions and oil quality adjustments must be deducted from the negotiated sale price.

Oil contracts, for both the domestic and export market, are almost always thirty-day evergreen contracts. So long as refiners are certain that oil production capability is in excess of their needs, security of supply will not be an issue in price negotiations. Although many perceive they should receive one, Canadian producers ought not to expect to be paid a premium over, for example, Iraqi oil, until the demand for oil outstrips supply capability.

\section{Export Pricing ${ }^{13}$}

At the time of writing, to remain competitive in the U.S. Midwest market, Canadian producers must be prepared to meet or beat the cost of

11. The source of information which follows is "Oil Exports Up Nearly 70 Per Cent in September 1985" (1986) IV:5 Conadian Energy News 35.

12. Much of the information in this section on domestic pricing and export pricing was obtained in discussion with Mr. E. Hobson, an employee of Northridge Petroleum Marketing, Inc.

13. Id. 
[VOL. XXV, NO. 1

West Texas Intermediate ("WTI") at Cushing, Oklahoma. The Chicago refiner will not be prepared to pay more for Canadian oil than the cost of his U.S. alternative, which is WTI, and, possibly, transportation from Cushing to Chicago. Due to present capacity problems on the Interprovincial Pipe Line Limited pipeline, ${ }^{14}$ alleged contamination of the Canadian product, and the provision to U.S. refiners of an incentive to switch to Canadian supply, Alberta producers must usually beat the WTI price and not just match it.

From this sale price are deducted transportation tariffs, sales commissions and quality adjustments and, in addition, a U.S. import duty's to obtain the producer net-back price.

As with the domestic market, the U.S. refiners are not willing, because of a current over-supply of oil, to pay any premium for security of supply. Indeed, with pipeline constraints on the Interprovincial system, Canadian sellers are not always able to meet their contractual obligations to deliver volumes under their U.S. contracts.

\section{INTRA-ALBERTA CONCERNS}

\section{A. ALBERTA PÉTROLEUM MARKETING COMMISSION}

In response to Clause 7 of the Western Accord, the Alberta Government reacted quickly to reduce the role of the APMC to that of merely a competitor with "buyers and sellers of oil in the private sector". ${ }^{16}$

\section{Pre-deregulation Role of APMC}

The APMC and its powers were established by the Petroleum Marketing Act" as part of a plethora of new statutes, regulations and amendments enacted in 1973 by the Alberta Government in response to a perceived "move to grab control of resources from the provinces". ${ }^{18}$

The APMC has been the exclusive agent of the Crown to market all petroleum produced under Alberta Crown leases - both its own royalty share of production ${ }^{19}$ and the lessee's share. ${ }^{20}$ The APMC accepted the oil at the outlet of a well battery or inlet of a feeder pipeline system ${ }^{21}$ and then contracted for the sale of the oil and paid the sale proceeds to the producers ${ }^{22}$ or to the operator. ${ }^{23}$ In addition, some producers sold their freehold oil to the APMC.

14. For a discussion of capacity problems on the Interprovincial system see infra at Part IV A.

15. At the date of writing, the U.S. import duty is about 114 per barrel.

16. "The Western Accord, an Agreement between Governments of Canada, Alberta, Saskatchewan and British Columbia on Oil and Gas Pricing and Taxation", 28 March 1985, clause 7.

17. R.S.A. 1980, c. R.5.

18. Tyerman, supra n. 2 at 428.

19. Petroleum Marketing Act, supra n. 17 at s. 15; Mines and Minerals Act, R.S.A. 1980, c. M15.

20. Petroleum Marketing Act, id. at s. 21; Mines and Minerals Act, id. at s. 118.

21. Canadion Energy Law Service, p. 30-117.

22. Petroleum Marketing Act, supra n. 17 at s-s. 21(1)(c).

23. Id. at s-s. 21.1(2) as am. S.A. 1983, c. 40, s. 3. 


\section{Implementation of Deregulation}

To comply with the Western Accord, the Alberta Government first had to deal with the Marketing Provisions Regulation, $1981,{ }^{24}$ which declared that all Crown royalty production and the lessee's share of production of petroleum and pentanes plus from all Crown agreements granting petroleum and natural gas rights or petroleum rights were to be sold through the APMC. By section 7 of the Petroleum Royalty Amendment Regulation, ${ }^{25}$ the foregoing regulation was repealed. At the same time, the Petroleum Royalty Regulations ${ }^{26}$ were amended, ${ }^{27}$ with the result that all Crown royalty production of petroleum continues to be delivered to the APMC.

\section{New Role of APMC}

The enactments described above fundamentally changed the role of the APMC. Since the Commission continues to sell the Crown royalty share of oil, it remains as a prominent broker or marketer of oil in Alberta. In addition, it continues to offer its sales services to independent producers. As of June, 1985, it was anticipated that the APMC would be responsible for about 300,000 barrels per day of Crown royalty production together with about 100,000 barrels per day of producers' oil ${ }^{2 s}$ (out of total production of roughly $1,600,000$ barrels per day). This anticipated ratio of APMC sales has been approximately borne out: of $1,100,000$ barrels per day production in March, 1986 about 300,000 were handled by the APMC. ${ }^{*}$ Other than the major oil companies, many producers continue to sell their oil through the APMC.

\section{Valuation of Royalty Share of Oil for Income Tax Purposes}

To the extent that the APMC no longer sells the lessee's share of production from Crown Lands, certain income tax concerns have arisen.

Section 12(1)(o) of the Income Tax Act (Canada) ${ }^{30}$ provides that any royalty which was "receivable" by the provincial Crown (or an agent, such as the APMC) is to be included in the income of the taxpayer.

An oil producer must be able to quantify the amount of royalty paid to the Crown in respect of Alberta Crown leases. As long as both the royalty share and lessee's share of Crown oil produced from Alberta Crown lands were marketed by the APMC, the required information was easily obtained. When the APMC forwarded sale proceeds to the operator, it would advise the operator of the total royalty paid to the Crown. The producers of the oil would thus be aware of the amount to be included pursuant to section 12(1)(0).
24. Alta. Reg. 443/81.
25. Alta. Reg. 154/85.
26. Alta. Reg. $93 / 74$.
27. Petroleum Royalty Amendment Regulation, supre n. 25 at s. 3.
28. "Alberta Comm. Plans to Play Key Role" (1985) IIl:35 Canadian Energy News 276.
29. Calgary Herald, 25 March 1986.
30. R.S.C. 1970 , c. I-5, as am. 
Industry, government and tax representatives met on October 31, 1985 to discuss the valuation problems that had resulted from deregulation and the proposed joint approach of Revenue Canada and Alberta Corporate Tax entitled "Deregulation of Oil Pricing Valuation of Crown Royalty Share" was presented to that meeting. Three possible situations for disposition of production (net of the Crown royalty share) were described as follows:

(a) an arm's length transaction by the operator/producer;

(b) a non-arm's length transaction - e.g. to an affiliate or parent corporation by the producer;

(c) refining by the producer.

In any one of the scenarios, the amount of royalty must be a "deemed" value, since the royalty share of production will be sold through the APMC while the producer's share will be dealt with separately and, possibly, at a significantly different price.

Based on its discussions with industry, Revenue Canada and Alberta Corporate Tax put forth these suggestions: ${ }^{31}$

(a) for each producer selling at arm's length, the royalty could be valued by reference to a "weighted average price" for each field. The "weighted average price" would be defined as:

"a total quantity of oil, from a particular field of the same quality, sold in the month divided into the total amount received for all sales of oil of that quality from that particular field:"

(b) for non-arm's length transactions (whether sales or used directly in refineries), a field posted price would be used or, if no field posted price, a fair market value, of oil of equivalent quality.

As of November 13,1985, it was expected that information letters would be released by Revenue Canada within "the next two to three months". ${ }^{22}$ To date, nothing has been released dealing with this problem.

\section{B. OIL PRORATIONING AND THE ENERGY RESOURCES CONSERVATION BOARD}

While the ERCB carries out a myriad of functions associated with oil and gas activities in Alberta, its administration of the Province's oil prorationing scheme has attracted the most attention since June 1, 1985. How, one questions, can deregulation really work if oil producers are protected by a plan which allows every producer to sell his product?

By Clause 6 of the Western Accord, the Province retains power "to ensure good conservation practice" and "to ensure equitable sharing of production". This role is, in Alberta, assumed by the ERCB.

31. "Deregulation of Oil Pricing Valuation of Crown Royalty Share", Revenue Canada and Alberta Corporate Tax, paper presented to meeting on 31 October 1985 of industry, government and tax representatives, at 2.

32. Memorandum dated 13 November 1985 by Mr. J. Poyen of the Independent Petroleum Association of Canada to all its members. 


\section{Rationale for the Prorationing Scheme}

When considering the rationale for oil prorationing, we are reminded of the childhood nursery rhyme, "This is the House that Jack Built". As we know, oil is a fugacious substance to which the "Rule of Capture" applies. In other words, you own what you can get out of a reservoir ahead of your neighbour. In certain jurisdictions, the result of this Rule has been uncontrolled drilling with no regard to good production practices. Since 1926, Alberta has had the statutory ability to impose spacing regulations which assist in more orderly development of oil reserves ${ }^{33}$ and, since 1933, the province has acted on that power.

However, regulation of well spacing ${ }^{34}$ does not help a mineral owner whose lands are subject to drainage. Accordingly, the Alberta Government protects, to a certain extent, such a person by the common purchaser provisions ${ }^{35}$ which allow someone whose lands are being drained to benefit from a contract held by the owner of the draining well. It is the foregoing system of regulation on regulation which led to the predecessor of the present prorationing regime.

\section{Legislative Authority}

Legislative authority for prorationing is contained in section 22 of the Oil and Gas Conservation Act, and its implementation is set forth in Part 10 of the Oil and Gas Conservation Regulations. ${ }^{36}$ By section 22(1):

22(1)

The Board may, by order, restrict the amount of oil and gas produced in association with the oil that may be produced in Alberta

(a) by fixing a provincial allowable for crude oil, condensate and pentanes plus not exceeding the market demand as determined by the Board,

(b) by allocating the provincial allowable for crude oil, condensate and pentanes plus in a reasonable manner among the producing pools in Alberta by fixing the amount of crude oil or condensate that may be produced from each pool, or of pentanes plus that may be produced from each plant, without waste, to meet the provincial allowable so determined, and

(c) by distributing the portion of the provincial allowable allocated to a pool in an equitable manner among the wells in the pool, for the purpose of giving each well owner the opportunity of producing or receiving his just and equitable share of the oil in the pool.

\section{History}

Prorationing has been "an integral part of the Alberta oil industry since December 1950". ${ }^{37}$ Problems associated with perceived inequities in oil

33. For a detailed discussion of well spacing in Alberta, the reader is referred to $R$. Harrison, "Regulation of Well Spacing in Oil and Gas Production" (1970) 8 Alta. L. Rev. 357.

34. Oil and Gas Conservation Act, R.S.A. 1980, c. O-5, s-ss. $10(1)$ (c.1) (d) (d.1), as am. and Oil and Gas Conservation Regulations, Alta. Reg. 151/71, Part IV as am.

35. Oil and Gas Conservation Act, id. at ss. 39, 40, 41; the rateable take provision in 5.23 of that Act applies only to gas.

36. Supran. 34.

37. ERCB, "Submission by the Alberta Energy Resources Conservation Board to The Restrictive Trade Practices Commission" (June 1983) 16. 
production and with drainage were first dealt with in respect of the Leduc discovery in 1947. The Continental Oil Company, an independent producer in the Leduc-Woodbend field, applied to the Petroleum and Natural Gas Conservation Board (a predecessor to the ERCB) to have Imperial Oil Limited declared a common purchaser for the field. After discussions and a public hearing held in October 1950, the Board accepted the principle of prorationing and published the first "Plan for Proration to Market Demand".38

It has always been considered by the ERCB (or its predecessors) that the scheme must respond to the changing needs of the industry. As was stated in the first Plan: ${ }^{39}$

We consider the plan to be preliminary to the extent that we will welcome suggestions for its simplification or improvement, and at a subsequent public hearing will give industry a further opportunity to express its views.

In 1957 and 1964, hearings were held and the scheme amended to deal with deficiencies. ${ }^{\circ}$ The last major hearing on the topic was held over a fiveday period from March 27 to April 9, 1974,41 to consider:"2

the need or otherwise for continuing the existing system of allocation of that portion of the provincial allowable for crude oil not supplied by synthetic crude oil. . . .

At that time, as a result of the increased demand for oil, most pools were producing at capacity (subject to conservation controls). The Board concluded that the plan should continue unchanged. In its report, the Board expressed certain of its reasons as follows: ${ }^{43}$

In order to satisfy one of the basic objectives of the Act, the ensuring of the opportunity of an owner to obtain his share of the production from wells in a pool, it is still necessary in a large number of pools to distribute the total production from the pool among the wells or production entities within the pool in an equitable manner. This need exists regardless of the relationship between market demand and total productive capacity. The Proration Plan was accepted by industry as a method of distributing production within a pool and if it were discontinued an alternative means for equitable distribution of production within pools would have to be substituted.

The Board also recognizes that the systematic issuance of the MD Order, the designation of fields, pools, PSUs, blocks and projects, and the follow-up through production accounting systems has become a widely used reference for control of production systems including individual wells, battery networks and field gathering systems. While this reference system has never been defined as a basic objective of the Proration Plan, it is a useful by-product. [Emphasis added.]

\section{Response to Deregulation}

Critics of prorationing have always existed. Since the Western Accord, there has been a groundswell of such criticism. For example, Mr. James

38. The Petroleum and Natural Gas Conservation Board, "Plan for Proration to Market Demand" (December 1950).

39. Id. at 1.

40. Oil and Gas Conservation Board, letter to all Operators "Re Proration Plan and the Economic Allowance" (30 August 1957) and Oil and Gas Conservation Board, "Report and Decision on Review of Plan for Proration of Oil to Market Demand in Alberta" (July 1964).

41. Energy Resources Conservation Board, "The Need or Otherwise for the Continuation of Proration of Alberta Crude Oil Production to Market Demand" (January 1975).

42. Energy Resources Conservation Board, "Notice of Hearing: Proration Plan and Maximum Rate Limitations", Proceeding No. 7511 (28 December 1973) 1.

43. Supre n. 41 at 22. 
Dunlap, president and chief executive officer of Texaco Canada Inc., has expressed the view that: 4

any form of prorationing clearly counteracts the idea of a free market that was part of the Western Accord.

and, further, that: ${ }^{45}$

the 'antiquated' prorationing system, developed in the early 50 's in response to a lack of markets for all available Alberta production, is damaging Canada's reputation as a secure source of oil.

Notwithstanding the critics, it is submitted that some form of prorationing may still be justifiable for the conservation and equitable sharing purposes for which the plan was originally implemented. While spokesmen for Texaco and for other large integrated oil companies may not agree, these purposes may be considered distinct from a "free market" concept. Indeed, the Western Accord in Clause 6 acknowledged the continued provincial role in conservation and equitable sharing.

However, just as the ERCB responded to changing times in 1950, 1957 and 1964, it has had to adapt to the effects of deregulation. Since deregulation took effect, Canadian refiners are no longer restricted in their sources of oil and the price of oil may be freely negotiated. ${ }^{45}$ As a result of these principles, it has been suggested that: ${ }^{47}$

Canadian refiners are increasing their purchases of cheap imported oil at the expense of domestic production.

Reduced demand by such Canadian refiners, at the time the purchasers' nominations are to be made to the ERCB, results in an ERCB Monthly Demand ("MD") Order, requiring greater volumes of oil to be shut-in.

In addition, there is now a lack of certainty in the oil markets - in part due to new players in the game and in part as a response to rapidly falling oil prices. No longer can purchasers accurately assess their needs for the next $\mathbf{4 5}$ days in order to submit nominations to the ERCB in the traditional manner. Increased activity in the spot market requires increased flexibility which has caused turmoil in the prorationing scheme.

Due, in part, to the foregoing and, to some extent, the fact that pipelines cannot presently handle all requested volumes, the amount of Alberta light and medium crude oil ordered shut-in under the primary market (which is discussed below) has increased since June 1, 1985. As reported March 12, 1986 in the Daily Oil Bulletin: ${ }^{48}$

In response to stiff competition since Ottawa deregulated crude pricing and marketing June 1 , the shut-in volume of light and medium oil production has increased, the ERCB says.

In the five months of 1985 prior to decontrol, for example, board ordered market demand shut-ins averaged 8,800 cubic metres per day, while in the seven post-decontrol months, shut-ins averaged 11,100 cubic metres per day. The 1985 statistics do not take into account volumes sold under the supplementary marketing program.

44. "Texaco chief calls for elimination of Alberta prorationing" (10 April 1986) Daily Oil Bulletin 1 and 2, reporting on a speech made by James Dunlap to the Edmonton Chamber of Commerce on 9 April 1986.

45. Id. at 2.

46. Western Accord, supra n. 16 at Clause 2.

47. "ERCB shuts in 249,000 bbls/day in April" (26 March 1986) Daily Oil Bulletin 1.

48. "Alberta Crude Production up only slightly in 1985" (12 March 1986) Daily Oil Bulletin I and 2. 
[VOL. XXV, NO. 1

The response of the ERCB has been the Supplementary Oil Sales System (described below), introduced in September 1985 and amended in March 1986, which allows a second wave of sales to take place for oil otherwise shut in as a result of an original MD Order.

\section{Procedures ${ }^{49}$}

The ERCB implements prorationing of the primary market in the following sequence of events:

(a) In each month, purchasers of Alberta oil file with the ERCB, by a date in mid-month set by the ERCB, their orders for oil (the "nominations").

(b) The Board, in a monthly hearing held three days after nominations are filed, establishes the "market demand", which is defined as "the amount of oil or gas reasonably needed for current consumption, use, storage and working stocks within and outside Alberta".so

(c) From the market demand is subtracted the production from the Suncor and Syncrude plants and pentanes plus production. None of the foregoing types of production or heavy crude production is subject to prorationing by the ERCB.

(d) The amount remaining becomes the "proratable demand", , which is made up of light and medium conventional crude oil.

(e) The proratable demand is then allocated amongst the approximately 2000 pools in the province and a Market Demand Order is issued on or about the 25 th day of the month to implement the production rates for the following month. The MD Order, which runs to over 200 pages, lists every pool, states the shut-in volumes for each pool and states the expected spare capacity on each of the major oil pipelines (Interprovincial, Trans Mountain and Rangeland).

(f) That portion of the proratable demand allocated to a pool is allocated equitably amongst the wells in the pool.

(g) If necessary, the MD Order may be amended at any time to reflect changes to shippers' nominations. Such changes may be due, for example, to a break in a pipeline or inability to deliver oil to a refiner. The ERCB attempts to make amendments to the MD Order by mid-month to allow producers to adjust production to the revised order but may issue amendments at any time.

If the MD Order in a given month results in oil being shut in and if pipeline capacity exists, the Supplementary Sales Program ${ }^{52}$ becomes operational and is applied in the following manner:

49. Portions of this section were written on the basis of discussions with Mr. R.L. Newman, Staff Specialist with the ERCB and Mr. F. Mink also with the ERCB.

50. Oil and Gas Conservation Act, supra n. 34 at s-s. 1(1)(I.1).

51. Oil and Gas Conservation Regulations, supra n. 34 at s-s. 1.020(2)(20).

52. As described in ERCB Informational Letter, IL85-14 "Supplementary Oil Sales under Alberta Prorationing System" (27 September 1985); ERCB Interim Directive ID85-3. "Regulations and Procedures to Accommodate Supplementary Oil Sales" (12 November 1985); and ERCB Interim Directive ID86-1, "Revised Regulations - Overproduction Penalties and Supplementary Sales Program" (31 March 1986). 
(a) The supplementary purchasers (for example, Amoco Canada Petroleum Company Ltd. and Northridge Petroleum Marketing Inc.) advertise their offers to purchase and such offers must be open to all producers.

(b) Producers may tender any or all of their available shut-in volumes to the supplementary purchasers, provided that the total being tendered plus the oil purchased under the existing MD Order does not exceed the MRL or "maximum rate limitation","s3 which is a rate of production prescribed for conservation purposes on a per hectare basis.

(c) Every Friday, purchasers notify the ERCB of the volumes that have been tendered and name the pipeline system which will be used.

(d) By the 15th of the month, supplementary market purchasers must file with the ERCB a nomination form for the preceding month which sets forth:

(i) the volume of oil actually purchased

(ii) a listing of all pools that tendered oil

(iii) the final disposition of all oil purchased (for example, name of refinery).

(e) Effective April 1, 1986, operators are required to submit the actual monthly data concerning crude oil sales to the supplemental market to the ERCB by the 15th day following the production month. ${ }^{54}$ This information can be used to cross-check the reports filed by the purchasers (step d).

\section{Problems}

While the foregoing sets forth a rather straight-forward mechanism, implementation of the Alberta prorationing system is rife with problems and potential for abuse.

The first difficulty occurs with respect to over-production penalties, which are applied when an operator in a pool (referred to as an "entity" by the ERCB) produces in excess of his monthly allowable."s By way of example, let us assume that the initial MD Order results in an allowable for the entity of 1000 barrels of oil for the coming month. By the 20th day of the month, the entity may have produced 900 barrels. If the ERCB were to issue an amended MD Order resulting in a revised allowable of only 800 barrels, the entity would immediately be subject to an overproduction penalty, since he had produced in excess of 110 percent of the allowable. Further, if he had contractual commitments to deliver more oil to a purchaser, he would be forced to incur more penalties. Certainly, if every producer produces ratably throughout the month, over-production would be almost impossible. However, a producer may have sound reasons for producing his total monthly allowable in a few days. For example, the well may require a workover or a replacement of some equipment.

53. Oil and Gas Conservation Regulations, supra n. 34 at s-s. 1.020(2)(10).

54. ERCB ID86-1, supra n. 52.

55. Id. 
This problem is not new, but appears to have increased since the deregulation of oil. In the first months of 1986, the MD Order has been amended downward in nearly every month. This makes even short-range planning very difficult for producers who are apparently being encouraged to underproduce for fear of overproduction penalties.

The second problem relates to the potential for abuse in the supplementary market. Purchasers of oil may wait for the supplementary market, which generally offers lower prices, rather than nominate in the primary market. Inherent in such a decision is the risk that pipeline capacity will be completely taken up by the Primary MD, at this time a very real risk in the Interprovincial system. It has been alleged that in mid-April 1986, a large refiner was offering $\$ 9.25$ (U.S.) per barrel for supplementary volumes when the world spot price was $\$ 12.34$ (U.S.). ${ }^{36}$ This abuse could continue only so long as refiners felt confident that excess oil supplies would exist. To date, the ERCB is of the opinion that this potential for abuse has not been realized, at least not within the Canadian market.

The ERCB, which has access to all information with respect to purchasers, is closely monitoring the purchasers and the ultimate users of crude oil to determine whether such users and purchasers are abusing the supplementary market." We could possibly see the ERCB scrap the supplementary market program to end such practices, if abuses were to occur.

Another concern is that, even with the supplementary market, prorationing results in a lack of flexibility. Oil sales, especially export sales, are often made quickly. The reporting, tendering, nominating and advertising requirements may be so onerous that sales to the United States are inhibited. This certainly has been the view of Mr. M.A. Kirkby, President of BP Canada Inc. , $^{\text {s8 }}$ a view with which the ERCB takes exception. It points to lack of capacity in the pipelines as the true cause.

Lastly, we would point out the problem of lack of accountability on the part of oil purchasers with the prorationing scheme in place for the primary market. In a normal contractual situation, the buyer and seller establish all the essential terms, such as price and volume, between themselves. Prorationing has, in part, removed the nexus between buyer and seller. While the producer remains obligated to deliver the contracted volumes of oil, the purchaser need only reduce his nomination to the ERCB to amend, in effect, unilaterally, the terms of his oil purchase contract. Because of the prorationing scheme, the effect of such an amendment would be diluted in the overall market. This appears to us to be inconsistent with the spirit of deregulation, although it should be noted that the Western Accord clearly states that the enumerated principles effect "oil price deregulation for Canada"."

56. "BP seeks change to crude allocation system" (24 April 1986) Daily Oil Bulletin.

57. Supra n. 49.

58. Supra n. 56.

59. Western Accord, supre n. 16 at Clause 10. 


\section{Future of Prorationing}

While problems exist in meshing the Alberta prorationing scheme with deregulation, it is submitted that some sort of prorationing plan may be necessary for the purposes of equitable sharing and conservation. However, it appears that more than fine tuning may be needed to respond to the changing markets and the emerging problems. The ERCB has historically shown itself to be willing to implement revisions in response to changing circumstances but, to date, no party has requested that the necessary hearing to review the plan be held. ${ }^{\circ}$

\section{OPERATIONS ON OIL PROPERTIES}

With legislated oil prices and, in Alberta, the APMC available to purchase all oil at the legislated price, pre-deregulation life was simple for Alberta producers. Each month, the operator of a well tendered his volume in response to the MD Order. Pipeline space constraints or shutdowns might have created a few disruptions, but otherwise marketing was an easy function.

Most oil wells in Alberta are operated pursuant to a form of operating procedure produced by the Canadian Association of Petroleum Landmen (commonly and herein referred to as the "CAPL Operating Procedure"), which sets out the rights and responsibilities of the operator ("Operator") and the other working interest owners ("Joint Operators") of the oil well.61 While disputes between an Operator and the Joint Operators are far from unheard of, the parties to the CAPL Operating Procedure rarely had any cause to argue about oil sales and pricing so long as oil prices were regulated. With deregulation, this peace may be disrupted.

\section{Operator's Role as Marketer}

The CAPL Operating Procedure focuses on the drilling of, maintenance of and other such operations on oil and gas properties and the only provisions dealing with marketing of oil are contained in Article VI. Pursuant to Clause 601, each party to the Operating Procedure has the right to take its own production in kind and to dispose of it separately.

In the event that the oil is not taken in kind, Clause 602 provides that:

When and so often as a Joint-Operator shail fail or refuse to take in kind and separately dispose of its proportionate share of any production, the Operator shall have the authority, revocable by that Joint-Operator at will (subject to existing sales contracts), to sell for the account and at the expense of that Joint-Operator its proportionate share of production to others at the same price which the Operator receives for its own share of the production or to purchase the same for its own account at the field price prevailing in the area. All sales made by the Operator of a Joint-Operator's share of production as aforesaid shall be for such periods of time only as are consistent with the minimum needs of the industry under the circumstances but in no event shall any contract for the sale of the Joint-Operator's share of production be made for a period in excess of one (1) year.

60. Supre n. 49.

61. The CAPL Operating Procedure has undergone numerous revisions. See R.M. Boyer, "The 1981 CAPL Operating Procedure" (1983) 21 Alta L. Rev. 82 for a discussion of the 1981 version of CAPL Operating Procedure. References herein are to the 1981 version unless otherwise stated. 
[VOL. XXV, NO.1

Clause 604 provides that proceeds from the sale of production must be distributed to the parties entitled thereto within 10 days of their receipt. Until the 1981 version of the CAPL Operating Procedure, even this fundamental obligation was not contained as an express term of the procedure.

Article VI and, indeed, the entire CAPL Operating Procedure is most noteworthy for its omissions regarding marketing. While there is an obligation on the Operator to: ${ }^{22}$

... carry on all operations diligently, in a good and workmanlike manner, in accordance with good oiffield practices and in accordance with the Regulations.,

"operations" do not specifically include marketing and there is no explicit obligation on the Operator to make a reasonable effort to market the oil at the best price available. Clause 602 gives the Operator the authority but not the obligation to sell the Joint-Operators' share of production. Given various markets available now in the deregulated environment, can the Operator proceed to tender oil on behalf of all parties without concern to price? In the event that an Operator tenders the oil to its own refining facilities, how does such Operator account to the Joint-Operators for the deemed sale? Finally, can the Operator choose to sell only its own share of production?

To date, the Canadian Courts have not gone so far as to impose the duties of a fiduciary or trustee on the Operator. ${ }^{63}$ However, in the Supreme Court of Canada decision in Midcon v. New British Dominion Oil, ${ }^{\text {,4 }}$ a case which dealt with the Operator's sale of production from jointly owned gas properties to a chemical fertilizer plant, Locke J., speaking for the majority, made some obiter comments concerning the extent of an Operator's duties in regard to his marketing function. ${ }^{65}$ Paraphrasing, in part, His Lordship stated that the company (the Operator) owed to the appellant (the Joint-Operator) "the duty to act in good faith in its efforts to sell [gas]". Further, in the event that the company "having in mind its own interest or prospective interest in the chemical company, negotiated a sale to that company at what was, to its knowledge, less than the fair value of the gas or less than could have been obtained ... I think an action for the resulting damage would lie". These comments would appear to answer the earlier posed questions to some extent - the Operator does have a duty, if not to obtain the best price, to act in good faith in obtaining an oil purchase contract and to account to the other owners for any difference between a "fair value" and the actual receipts in a non-arm's length transaction. It should be noted that the operating agreement in place in the Midcon case did not allow for a Joint-Operator to take its production in kind. In such a situation, it is submitted the duty of the Operator would be higher than in a CAPL Operating Procedure.

The answer to the final question posed appears, from a literal interpretation of Clause 602, to be that an Operator can theoretically refuse to sell the Joint-Operators' share of oil production. To our knowledge, this potential

62. 1981 CAPL Operating Procedure, Clause 304.

63. Midcon v. New British Dominion Oil [1958] S.C.R. 314 (S.C.C.).

64. Id.

65. Id. at 326 . 
situation has never arisen. Practically, it would be almost impossible to account to the Joint-Operators for that share of production taken by the Operator and, at the same time, that share shut-in for the Joint-Operator. One solution to the problem would be to amend Article VI to require the Operator to sell all production for the joint account if the Joint-Operator does not exercise its option to take in kind.

\section{Taking in Kind}

As referenced above, each party to a CAPL Operating Procedure has the right to take his share of production in kind. As an effect of deregulation, we may see an increase in the number of producers choosing to market their own oil. This may create severe headaches for the Operator, who must account to each of several Joint-Operators who choose to take in kind as well as to other Joint-Operators of the same property, who continue to allow the Operator to sell their share.

With freely negotiated and rapidly changing oil prices, one JointOperator may be quite willing to shut-in his share of production pending more stable and higher prices. While the CAPL Operating Procedure allows the Joint-Operator to take in kind, it does not permit him to shut-in his share. The Operator would have the authority, pursuant to Clause 602 , to take and market that Joint-Operator's production. Unless the affected party can arrange alternative storage facilities or can persuade all other parties to agree to shut-in the well, the Joint-Operator will have no alternative but to allow his oil to be sold and he will have no recourse against the Operator.

A possible solution to the problems associated with split sales of oil production could be a provision in the CAPL Operating Procedure for an oil balancing agreement. The need for gas balancing agreements in certain situations has been seen in the United States for some time and, in the Canadian context, was recently discussed in an Alberta Law Review paper written by Mr. Jay Park. ${ }^{66}$ Mr. Park briefly described the mechanics of a gas balancing agreement as follows: ${ }^{67}$

The gas balancing agreement provides that a joint owner may produce more than its
respective share of production from time to time and may receive the revenue for it. The
parties who have not produced their respective share do not receive a portion of the
production revenue, but they do earn a gas-in-storage "credit" equal to the amount of the
underproduction. An underproduced party may then recover its underproduction by
taking more than its respective share of production in the future, up to a limit of 50
percent of the proportionate share of production of the overproduced parties. This 50
percent limit is a negotiable figure.

Negotiating and implementing an oil balancing agreement would be similar to that for gas balancing, but would have to take into account the vagaries of oil production. For example, the Alberta prorationing scheme, which could lead to unanticipated overproduction penalties, would have to be considered.

While the CAPL Operating Procedure allows a producer to take in kind, there are situations where taking oil in kind is not practical. For some small junior oil companies with minor working interests in several fields, the

66. J.J. Park, "Developments in Natural Gas Purchase Contracts" (1984) 22.Alta. L. Rev. 43.

67. Id. at 55 . 
time and expense involved in contracting for the sale of oil may not be justified. In other cases, the interests of a participant may be held in trust and, hence, not recognized by the Operator. Such a participant would not have the standing necessary to force an Operator to deliver his share of oil. In these situations, oil balancing agreements would not resolve the problems and, perhaps, the parties may wish to consider amendments to the CAPL Operating Procedure to increase the duties on an Operator or other party selling oil for a joint account.

\section{EXTRA-PROVINCIAL CONCERNS}

\section{A. PIPELINES}

Having flowed through Alberta's partially deregulated maze, about 80 percent of the Alberta production is thereupon shipped out of the Province from Edmonton and Hardisty via the two main oil transmission systems, namely the Trans Mountain Pipe Line Company Ltd. ("Trans Mountain") facilities to Vancouver and the Pacific Northwest of the United States, and the Interprovincial Pipe Line Limited ("IPL") system to the United States Midwest, Ontario and Quebec. A much smaller quantity is exported to Montana via the Rangeland System.

Pipeline operations and their regulation are the constants of a changing business, although even here some effects of deregulation have been felt. The remarks in this paper relate to the federally regulated lines referred to above and not to the smaller feeder systems which bring oil from various parts of the Province of Alberta to the long distance transmission facilities.

The Western Accord did not mark the recommencement of light crude exports. That process had begun earlier, when it was realized that Canada had surplus production which could be spared for the export market. However, the strict pricing and export tax regime did persist until dismantled by the Western Accord. Exports led to increases in demand for space, particularly on lines 2 and 3 of the IPL system which carry heavy and light crudes in combination. When demand for space exceeded supply, IPL initiated apportionment pursuant to a scheme instituted in 1979, whereby entitlement to space was based on historic usage. Its authority for so doing is contained in section 59(1) of the National Energy Board Act, which reads:

59.(1) Subject to such exemptions, conditions or regulations as the Board may prescribe, a company operating a pipeline for the transmission of oil shall, according to its powers, without delay and with due care and diligence, receive, transport and deliver all oil offered for transmission by means of its pipeline.

Accordingly, IPL had instituted its historic usage tariff, as approved by the NEB, which read: ${ }^{\circ}$

When, pursuant to Notices of Shipment hereunder, there shall be offered to the Carrier more Petroleum than can be immediately transported, the transportation shail be apportioned by the Carrier among all Shippers on an equitable basis, with due consideration being given to the historical use which each has made of the Carrier's facilities and to the current operating conditions of the Carrier's pipeline.

68. R.S.C. 1970, c. N-6, as am.

69. Interprovincial Pipe Line Limited, “Tariff Applying on Refined Petroleum Products by Pipe Line", NEB No. 126, 1 May 1984, para. 15. 
While such a system may have sufficed in earlier days when buyers were few and unchanging, it did not satisfy the new shippers who were allocated a small 5,000 barrel/day share in the line. This led to a complaint by Northridge Petroleum Marketing Inc., one of the new shippers, pursuant to section 55 of the National Energy Board Act, ${ }^{\circ}$ which states:

55. A company shall not make any unjust discrimination in tolls, service or facilities against any person or locality.

The NEB rejected Northridge's complaints, on the basis that the new shipping provision applied to all new shippers and was part of a published tariff of IPL. It nevertheless decided to hold a public hearing to look into the matter "... in view of the imminent changes in oil regulation ..."." The resulting hearing started in late May of 1985 and the decision flowing from it concluded that a current tenders method of apportionment was the preferred choice, albeit with modification to give some priority to "end use destinations not capable of being supplied economically from alternative sources"."

A current tenders method of apportionment means what its name implies. IPL gathers all the requests for space for the ensuing months and determines if there is sufficient space in the line. If all requests for space cannot be met, all are cut back in proportion to their original allocation. There are safeguard mechanisms to ensure that unrealistic and unwarranted requests for space are not made in the first place.

The NEB, perhaps influenced by the winds of deregulation blowing in Ottawa, seemed disinclined to preserve the entrenched rights of historic users of IPL. Notwithstanding evidence of assurances by various levels of government that non-conventional oil would not suffer from production limitations, the decision refused a request for line space priority for such production. The argument for special treatment was especially strong from synthetic crude producers. It will be recalled that, before the Syncrude project proceeded, for instance, there were numerous meetings among the project sponsors and the governments involved. Indeed, some of the governments became investors. Synthetic and heavy crude oil producers in particular are feeling the effects of depressed crude oil prices. Assuming that they wish to have continued access to market, there may be further pressure from such producers for priority in the IPL line should apportionment remain a problem.

Following the IPL apportionment decision, Trans Mountain voluntarily submitted to a similar scheme in its line to Vancouver and Anacortes, Washington. Demand for space on Trans Mountain is not as great, since prices realizable on the West Coast do not produce the net-backs available to Alberta producers from sales to Eastern Canada and the U.S. Midwest. Consequently, apportionment has not yet been required on the Trans Mountain System.

70. Supra n. 68.

71. NEB letter to Northridge Petroleum Marketing, Inc. dated 18 April 1985 and reproduced as an appendix to the National Energy Board Decision of July 1985 on Hearing Order MH-3-75, infra.

72. NEB Decision on Hearing Order MH-3-85, July 1985, at 7. 
In addition to the apportionment hearing, IPL has recently been before the NEB with applications for increased facilities. In the face of increasing throughputs, IPL had applied in the fall of 1984 for increased capacity which was duly approved and implemented in late 1985. Even then, it had been realized that IPL would have to do more to take care of increasing traffic demands and application was made in February 1985 to increase the capacity of lines 2 and 3 by 25,000 cubic metres a day (roughly, 157,000 barrels a day). A hearing was held in Ottawa in late February of 1986. Parties attending were unanimous in favouring increased capacity, which may account for the fact that a short five-day hearing was all that was needed to dispose of an application to spend approximately \$235 million in Canada. NEB approval was relatively swift and a decision has already been issued and has received Cabinet approval at this writing. Assuming expeditious construction, the new facilities could be in place by the last quarter of 1987 . They will result in a $16 \mathrm{c} / \mathrm{barrel}$ increase in the existing toll of $\$ 1.13$ to Sarnia.

Little else has changed for the long pipelines. Their tolls continue to be regulated by the NEB. It has already been observed that facilities applications also require NEB approval. Nevertheless, their place in the scheme of things cannot be underestimated. While the removal of some red tape undoubtedly made Canadian petroleum a more attractive commodity in the United States Midwest, reservations in purchasing Canadian petroleum persist because of capacity limitation and, more recently, complaints of the product becoming contaminated while passing through the IPL line.

\section{B. EXPORT OF OIL}

It is at the 49th Parallel that the greatest effects of deregulation are felt. The complex pricing scheme described in the Alberta Law Review a few years $\mathrm{ago}^{7 \mathrm{~s}}$ is gone, replaced by a net-back pricing scheme more responsive to market forces and described earlier in this paper. The requirements to export oil in the short term are comparatively simple. Naturally, one requires contracts of sale and supply and the means of transportation. The approval procedure thereafter is straightforward, although not quite as simple as promised in clause 5(ii) of the Western Accord. Part VI of the National Energy Board Act continues to apply. Section 81 prohibits unlicenced exports of oil "except as otherwise authorized by or under the Regulations ... .. In this case, the relevant regulations are the National Energy Board Part VI Regulations." Section 10 of those Regulations stipulates that any licence to export heavy crude for a period exceeding two years, or oil other than heavy crude for any period, is subject to the approval of the Cabinet. However, that section is substantially qualified by section 26(1) of the same Regulations, which states:

26.(1) The Board may take an order authorizing any person,

(a) for a period not exceeding two years, to export heavy crude oil; and

(b) for a period not exceeding one year, to export oil other than heavy crude oil.

73. Supre n. 2.

74. C.R.C. 1978, c. 1056, as am. 
Inasmuch as virtually all oil exports are made on a short term basis, this is a fairly major exception.

Section 26 is, in turn, qualified by section 27 which states:

27. Where, pursuant to Section 26, the Board makes an order authorizing a person to export oil, the Board may make the order subject to one or more of the following terms and conditions:

(a) every contract or agreement the person enters into for the exportation of that oil for a period exceeding one month shall contain a clause relieving that person of the obligation to export the oil to the extent that authorized exports are restricted by the Government of Canada; and

(b) the person shall furnish to the Board, for each month, not later than the last day of the next succeeding month, reports in the form set out in the schedule.

The net result is that a significant distinction exists between licences requiring more formal approvals and orders for shorter term contracts which can be obtained ex post facto. Presumably, the thinking of the Federal Government is that it can move quickly to decrease or terminate short term exports, whereas that flexibility would not exist with longer term licences.

Accordingly, the procedure for short term exports is that an exporter must be registered in advance with the NEB by means of a renewable annual order. Details of that exporter's previous month's transactions are forwarded to the Board early in the following month. Required information consists of identifying the crude oil stream, the consignee, the destination, the volume, the acquisition cost, the export transportation system, the point of sale, the export price at the point of sale and, if applicable, the marine freight charges on CIF sales. In the event petroleum products are exported, they are detailed on a separate form.

\section{ROLE OF GOVERNMENTS}

Ongoing government activity in the production, sale, movement and export of petroleum can be gleaned from preceding portions of this paper. At the provincial level, the role of the APMC has declined substantially. Nevertheless, the Government of Alberta is still entitled to a significant royalty and the disposition of this interest alone makes the APMC an important participant in the market. Lately, with drastically declining oil prices, there have been suggestions that the APMC should buy up a portion of Alberta's daily production and dispose of it in the export market as a means of propping up the domestic price and raising producer returns. At the date of writing, it remains to be seen whether the Alberta Government will be persuaded so soon after deregulation to re-enter the market and create artificial forces within it.

Regulation through the ERCB can be expected to continue. Most people would agree that good conservation practices should be maintained. However, as outlined, there are other means besides the prorationing system to effect this. Although there has been grumbling, there have not yet been formal requests for a hearing to consider the prorationing question, although such a hearing has certainly not been ruled out by Mr. Vern Millard, Chairman of the ERCB. ${ }^{75}$

75. V. Millard, "Proration and Deregulation Under the Western Accord" Speech to Natural Resources Section of the Canadian Bar Association Dinner Meeting, Calgary, Alberta, 22 October 1985. 
[VOL. XXV, NO. 1

It is at the federal level that the greatest change in government roles has been seen. As a result of the Western Accord, the federal government removed itself from the complex scheme set up by the previous government. With a series of Orders-in-Council, ${ }^{76}$ it effectively terminated the export levies on oil products, the Petroleum Compensation Program, the petroleum levy which helped pay for the compensation program, the crude oil price setting for Northwest Territories production and the Canadian Ownership Special Charge. Reference is also made to Appendix I of the paper which has more details. Those who feel that such programs have disappeared forever should bear in mind that the Energy Administration Act $^{n}$ has not been repealed and the Orders-in-Council referred to generally accomplished deregulation by setting the various charges and payments at zero. These programs could all be reintroduced with alacrity and, indeed, Clause 9 of Part I of the Western Accord makes it plain that the Government of Canada reserves such a right. It should also be borne in mind that the willingness of the Government of Canada, at least, to enter into deregulation may have been prompted strongly by the burdensome expense of maintaining the Petroleum Compensation Program.

Some years ago, a few brave (or perhaps foolhardy) individuals suggested that Canada and the United States should have a continental energy policy or essentially one market for the two countries. With the deregulation of oil and oil products, it is suggested that that situation now exists. True, there are limits which would enable the Government of Canada to move quickly to divert Canadian supplies to Canadian markets. A small import levy continues to be imposed by the United States. We are, nevertheless, extremely close to complete free trade in petroleum, particularly when contrasted to the situation with natural gas. Gas exports are required to meet the adjacent border price test whereas oil is not. Gas exports, under licence, cannot take place without satisfying the reserves test in place from time to time. Oil does not have a similar restriction. The differences no doubt arise from the tradition of long contractual periods in the natural gas industry and the relative ease of transportation of petroleum in contrast to natural gas. While the maintenance of the present deregulated environment for oil would appear brighter than for natural gas, one should conclude with the observation that many predictions in the energy business have proved wrong over the last decade and it can be expected that this trend will continue. 


\section{APPENDIX "A" \\ CHANGES EFFECTED TO OIL PRICING AND MARKETING BY WESTERN ACCORD*}

\begin{tabular}{|c|c|c|}
\hline & PRE-DEREGULATION & POST JUNE 1, 1985 \\
\hline $\begin{array}{l}\text { Petroleum Compensation } \\
\text { Charge (PCC) }\end{array}$ & $\begin{array}{l}\text { - All domestic and foreign crude } \\
\text { oil and imported petroleum } \\
\text { products consumed in Canada } \\
\text { bore the PCC, curently at } \\
\text { \$41.14 per cubic metre. } \\
\text { - Exports of products were } \\
\text { eligible for rebates of the PCC }\end{array}$ & - No longer imposed \\
\hline $\begin{array}{l}\text { Petroleum Levy Offset } \\
\text { Program (PLOP) for } \\
\text { Petrochemical Producers }\end{array}$ & $\begin{array}{l}\text { The last increase in the } \\
\text { Petroleum Compensation } \\
\text { charge was } \$ 17.30 \text { per cubic } \\
\text { metre on November 10, } 1984 \\
\text { (as announced in the Economic } \\
\text { Statement of November } 8 \text {, } \\
\text { 1984). } \\
\text { - PLOP provides an offset } \\
\text { against that increase for } \\
\text { certain primary petrochemical } \\
\text { products. }\end{array}$ & $\begin{array}{l}\text { - Program ends with } \\
\text { elimination of PCC }\end{array}$ \\
\hline $\begin{array}{l}\text { Primary Industry Levy } \\
\text { Offset Program }\end{array}$ & $\begin{array}{l}\text { - As part of the Fuel Tax Rebate } \\
\text { Program those in primary } \\
\text { industries (farmers, fishermen, } \\
\text { and those involved in logging, } \\
\text { mining, hunting and trapping) } \\
\text { are eligible for a } 1.84 \text { per litre } \\
\text { PCC rebate. }\end{array}$ & $\begin{array}{l}\text { - The } 1.8 c \text { per litre PCC } \\
\text { rebate ends with } \\
\text { elimination of PCC. } \\
\text { - The } 3.06 \text { per litre } \\
\text { Federal Sales Tax rebate } \\
\text { continues. }\end{array}$ \\
\hline $\begin{array}{l}\text { Controlled Prices on } \\
\text { Conventional Old Oil } \\
\text { (COOP) }\end{array}$ & $\begin{array}{l}\text { - The price of oil discovered } \\
\text { prior to } 1974 \text { is controlled by } \\
\text { agreement with the provinces } \\
\text { at below world levels. } \\
\text { - About } 45 \text { percent of domestic } \\
\text { oil is affected. }\end{array}$ & $\begin{array}{l}\text { - Producers sell their oil at } \\
\text { market price. } \\
\text { - Refiners pay market } \\
\text { price. } \\
\text { - Government does not set } \\
\text { the price. }\end{array}$ \\
\hline $\begin{array}{l}\text { New Oil Reference Price } \\
\text { (NORP) for Synthetic } \\
\text { Crude Oil }\end{array}$ & $\begin{array}{l}\text { - Producers of synthetic crude } \\
\text { eligible for the international } \\
\text { price and receive compensation } \\
\text { based on a complex calculation } \\
\text { similar to that employed for } \\
\text { conventional new oil. }\end{array}$ & $\begin{array}{l}\text { - Price set by market place } \\
\text { not by government } \\
\text { - No compensation }\end{array}$ \\
\hline $\begin{array}{l}\text { New Oil Preference Price } \\
\text { (NORP) for Conventional } \\
\text { Crude Oil }\end{array}$ & $\begin{array}{l}\text { - Producers of qualifying new } \\
\text { oil in five producing provinces } \\
\text { and the territories are paid } \\
\text { compensation for difference } \\
\text { between international price } \\
\text { and controlled domestic price. } \\
\text { - Compensation based on } 81 \\
\text { different NORP prices } \\
\text { calculated from prices of } 54 \\
\text { foreign crudes at Montreal, } \\
\text { subject to detailed federal - } \\
\text { provincial administrative } \\
\text { manual. }\end{array}$ & $\begin{array}{l}\text { - Producers sell their oil at } \\
\text { market price. } \\
\text { - Refiners pay market } \\
\text { price } \\
\text { - Government does not set } \\
\text { the price or pay any } \\
\text { compensation. }\end{array}$ \\
\hline
\end{tabular}




\begin{tabular}{|c|c|c|}
\hline $\begin{array}{l}\text { Oil Import Compensation } \\
\text { Program (OICP) }\end{array}$ & $\begin{array}{l}\text { - Payments made to oil } \\
\text { importers based on the } \\
\text { difference between the average } \\
\text { cost of foreign and } \\
\text { equivalent-quality Canadian } \\
\text { cude oil at Montreal. } \\
\text { - Io protect markets for } \\
\text { Canadian production, access } \\
\text { to international market was } \\
\text { restricted. }\end{array}$ & $\begin{array}{l}\text { - No import } \\
\text { compensation necessary } \\
\text { - No restrictions on } \\
\text { imports }\end{array}$ \\
\hline $\begin{array}{l}\text { Domestic Transfer } \\
\text { Compensation }\end{array}$ & $\begin{array}{l}\text { - Compensation granted for } \\
\text { costs of moving domestic } \\
\text { crude to refineries east of } \\
\text { Montreal. }\end{array}$ & $\begin{array}{l}\text { - Such movements to be } \\
\text { on a commercial basis. }\end{array}$ \\
\hline Crude Oil Export Charge & $\begin{array}{l}\text { - a charge is recommended by } \\
\text { the National Energy Board on } \\
\text { all exported crude oil and } \\
\text { petroleum products. The level } \\
\text { is equal to the difference } \\
\text { between the selling price and } \\
\text { the lower Canadian-controlled } \\
\text { price. } \\
\text { - Export charge revenues on } \\
\text { crude oil split so-s0 with the } \\
\text { province of production. } \\
\text { - The revenues on products } \\
\text { accrued entirely to the federal } \\
\text { government. }\end{array}$ & $\begin{array}{l}\text { - Export charge } \\
\text { eliminated }\end{array}$ \\
\hline Crude Oil Export Licences & $\begin{array}{l}\text { - NEB licence required for all } \\
\text { crude oil exports and for most } \\
\text { petroleum products. }\end{array}$ & $\begin{array}{l}\text { - Monitoring of exports } \\
\text { will continue but prior } \\
\text { approval will not be } \\
\text { required for exports of } \\
\text { light crude oil and } \\
\text { petroleum products less } \\
\text { than one year, and heavy } \\
\text { crude less than two } \\
\text { years, in duration. }\end{array}$ \\
\hline Import Licences & $\begin{array}{l}\text { - NEB licences required on } \\
\text { imports of heavy fuel oil. }\end{array}$ & - No licences required. \\
\hline
\end{tabular}

